ARTICLES

\title{
PROMOTION OF LEGAL CULTURE AS A FACTOR OF NEW STAGE IN INTEGRATION. FROM THE COMMUNITY OF LEGAL VALUES TO THE COMMUNITY OF LAW ${ }^{1}$
}

\author{
by Tadeusz Biernat
}

\begin{abstract}
The basis of European communities' integration is diversified. Some of its aspects are particularly emphasized, like the dynamics of economic development, which creates new quality of life for millions of Europeans. Much attention is devoted to the common historical past and the common democratic political values. The attention is focused, to a lesser extent, on what constitutes the real basis of cultural identity for European societies, namely law and the attitude to it. It is law and values attributed to it as well as legal institutions, which have been the strongest links of cultural chain connecting Europeans. Except for a basic issue, that is the Roman law tradition, one can point at a great common achievement with essential practical qualities. Lex mercatoria in the field of commercial law. Traditions of European constitutionalism, including the second, in the terms of the time of creation, modern constitution which was Polish constitution of 1791. Modern civil law becoming widespread due to the French Napoleonic Civil Code, which at the beginning of the $19^{\text {th }}$ century was binding on the eastern European territory within such borders,

1 A part of the thesis included in this paper was presented on IX Conference "European Culture", Pamplona 24-27 October 2007. Another part was also the subject of my presentation on the International Conference "European Constitution and National Constitutions", organized by Andrzej Frycz Modrzewski Krakow University College, the Jagiellonian University, University of Hull, Krakow, 21-24 October 2007.
\end{abstract}


which are now the European Union's borders. The exchange of ideas and legal doctrine from the Middle Ages at European Universities. Promoting in these discussions, starting from the $16^{\text {th }}$ century, modern solutions in the area of law, like the postulate of departing from capital punishment and equal rights. A systematic development of subjective rights, human rights, equal rights for women, rights of minorities and rights of the disabled. Introducing these rights to the positive law and ensuring their international and institutional protection.

The analysis of the above mentioned examples constitutes the basis to formulate the thesis that the shared values, which refer to law and which are attributed to law, as well as commonly accepted legal institutions, are one of the most essential cultural factors integrating the European community. It was used at the moment of the creation of European communities, in a later stage of the European community which is, above all, the community of law. Emphasizing this fact allows to look at the process of European integration from a different perspective and, consequently, it enables to take intense actions for the benefit of creating a European constitution which will be accepted by the Europeans.

\section{LEGAL TRADITION AND CULTURE}

The thesis about the influence of legal culture on law and its application, on social and economic relations and on the dynamics of political systems is commonly acknowledged and exploited. It can be seen both on the example of rich and fast growing literature of the subject and when taking into consideration the fact that scientific researches devote increasingly more attention to these issues ${ }^{2}$.

What is stressed in these researches is also the fact that legal culture has very strong bonds with tradition. As Mark van Hoecke writes:

"Culture is often linked to a more or less long-lasting tradition, during which all this has been created, developed and fixed. (...) Legal cultures are generally based on a long tradition and even aim at keeping it unchanged for as long as possible" (Hoecke 2007, 82-83).

It is worth pointing at the consequences of such interdependence between tradition and culture generally and tradition and legal culture in particular. Such interdependence allows both for inferring the thesis that a diverse tradition of legal institutions, legal solutions, and generally speaking law within the state, is the basis

2 These issues constituted the central theme of the 23rd IVR World Congress of Philosophy of Law and Social Philosophy in Krakow (Poland) which was held on 1-6 August 2007 Law and Legal Cultures in the 21st Century: Diversity and Unity. 
to distinguish diverse 'cultures of law'. We can then talk about French, German, Spanish, or Polish legal culture. If we, however, take into account such legal institutions, such solutions or such rulings, which share common features occurring in the traditions of various countries, it seems proper to draw the conclusion concerning their common legal culture. Pointing at such thesis, which is more proper, does not depend on subjective judgement but on what significance common or similar legal solutions have for a proper functioning of legal and social system. The latter can be illustrated on the following example. Legal solution, which occupies particular position in the tradition of European constitutionalism, is the one, which is included in Article 16 of the Declaration of the Rights of Man and of the Citizen of 1789:

"Any society in which the protection of rights is not guaranteed and the separation of powers is not established, has no Constitution".

According to the above mentioned article, such solutions as 'the separations of the state powers', which are well known from the tradition of European political thought and the tradition of legal doctrine, have become the basis of commonly binding patterns of legally oriented social attitudes. This process was also seen as:

"(...) the development of the paradigms that embody the relationship between the formulation of human rights and approaches to their achievement, the relationship between participation and representation, as well as the relationship between norms and hermeneutic" (Policastro 2004, 59).

The process of popularising this solution in many European countries, manifested by the appearance of similar legal solutions, has become not only the basis of a common, European tradition but it has also constituted the basis of the appearance of ideas and beliefs so significant for legal culture as for instance those concerning impartiality of judges. The paradigm of legal culture is based on the appearance of beliefs and attitudes but it refers to issues fundamental for every legal system.

"This paradigm consists of basic views on the concept of law, legal sources, the methodology of law, legal argumentation, the legitimization of law and, more generally, some common values and world views. Such views may change over time, but only slowly. Legal rules may be changed from one day to the other, but the way these rules will be handled, interpreted, and applied will still be governed by the, unchanged, legal culture" (Hoecke 2007, 84).

In the abstract of this study, I point at the appearance of such significant facts in the tradition of European states, which have greatly influenced the shape of European legal culture. The examples, which have been chosen, and which could be easily supported with further ones, constitute only an illustration of the phenomenon in question. When discussing them I referred to the world's second, in terms of the time of creation, after the constitution of the USA, modern constitution which was Polish constitution of 1791. This constitution, known as the Constitution of May 3, was an 
expression of a revolutionary approach to the shape of social order, introducing as a principle codification and writing down the fundamental rights. It shaped the principles of a democratic system, it introduced political rights, though only for a part of citizens, about $10 \%$ of the whole population, but it was nevertheless a very progressive solution compared to other countries. The constitution in question introduced the principle of separation of powers and it guaranteed the freedom of religion. It included innovative solutions concerning administrative issues and, what should be emphasised, innovations in organization of education. Its specific provisions include a number of original solutions, for instance the one that once every 25 years the Sejm, having legislative power, will be granted the status of constituent assembly, namely the body entitled to a review of the constitution ${ }^{3}$.

I carry out a more detailed analysis of this example not only due to the fact that it is close to me as a Pole, but also in order to show and emphasise that common European constitutional tradition, which shaped European legal culture, was not only created in western European countries but in such countries as Poland too.

An even more telling example of how important traditions were shaped far from the European centre is the reception of the French Napoleonic Civil Code, which at the beginning of the $19^{\text {th }}$ century was binding on eastern European territory within such borders, which are now the European Union's borders. The French Napoleonic Civil Code was passed in France by an Act of March 21, 1804, as Code civil des Français, Code Napoléon. It was based on the premises of equality, freedom, individual property and freedom of contracts, realizing principles of civil law4. Three years later the Napoleonic Civil Code was rendered as civil law in the Duchy of Warsaw under article 69 of the Constitution of July 22, 1807. The act of enacting this Code was confirmed by the decree of enacting the Napoleonic Code in the Duchy of Warsaw becoming effective on $1^{\text {st }}$ May, 1808, issued by Frederick August, a Saxon king, the Duke of Warsaw. Introducing many innovative solutions, the Code was not only the first such a thorough codification but it constituted the basis for the development of civil law institutions and it contributed to establishing patterns which were characteristic for legal culture as a part of continental legal system.

3 More on the issue of the Constitution of May 3 see: J. Jędruch, Constitutions, Elections and Legislatures of Poland, 1493-1993, EJJ Books, New York 1998.

4 The Code consists of 2281 articles divided into preliminary title (articles 1-6), and three books: Book one - of Persons (art. 7-515), this book also included provisions concerning enjoyment and loss of civil rights, about acts before the civil authorities, provisions concerning marriage, provisions on paternity and affiliation, adoption and guardianship; Book two - of property and different modifications of property (art. 516-710); Book three- of the different modes of acquiring property (art. 711-2281). 
The factors, which contributed to the creation of sui generis legal culture, were as follows: the process of shaping legal tradition in Europe as a result of enacted legal acts, implemented solutions, the development of legal doctrine and the philosophy of law and the influence of numerous centres promoting the ideas connected with law, including such significant ones as universities. Its characteristic feature is, among others, to attribute special position to law in shaping social order. It is manifested in the commonly accepted principleof the rule of Law, which resembles the idea of Rechtsstaat. These conceptions appear in different kinds of normative acts in the scope of European law and they are treated in equivalent way to the notion of the rule of Law, to give only one example. The term the rule of Law, which has been emphasised in many monographs, is ambiguous. ${ }^{5}$ It is also manifested in the perception of law as personifying and expressing fundamental values for the culture of European value. It was the basis for the thesis that the shared values, which refer to law and which are attributed to law as well as commonly accepted legal institutions, are one of the most essential cultural factors integrating the European community. I discuss two problems on the basis of the latter. The first concerns a characteristic of the already shaped European community. The second one pertains to a further stage of European integration, connected with an aspiration to implement the European constitution.

\section{THE ROLE OF LAW AND LEGAL CULTURE IN THE CREATION OF THE EUROPEAN COMMUNITY}

Differences between the modern state and the European Union are deeper than it is stressed, and refer to the institutional and organizational level, or even to the national identity of member states' citizens and a lack of identity of Europeans. In short, the modern state is a product of general political objectives, where the idea of rational and optimal social order, regarded as a manifestation of common will and an act of striving for the best possible world, is being realised. Likewise, the best possible political system - the system of government and the legal system - is being realised there. The constitution plays a central role in those systems, and so the social

${ }_{5}$ F. d'Agostino: The State Under the Rule of Law [in:] European Democratic Culture, N. Parker (ed.), Routledge, 1993 p. 114. The author of the monograph explains what follows: The term 'Law' (with a capital 'l', and without an article) is used throughout this essay to convey something of the continental Recht, droit, etc., with their connotation of a meta-legal sphere above and beyond the positive law of particular state. 
and political legitimacy is the basis for the constitution-making activity. In particular, democratic legitimacy is regarded as conditio sine qua non.

The validity of the state (the state as value) is the principal value of the system that is being created. ${ }^{6}$ It is seen in Constitutional acts, as e.g. the Constitution of the Republic of Poland of $2^{\text {nd }}$ April 1997. Article 1 states:

"The Republic of Poland shall be the common good of all its citizens" and Article 2: "The Republic of Poland shall be a democratic state ruled by law and implementing the principles of social justice."

The European system, as a kind of multi-level and multi-dimensional polity, has its own social, economic and political objectives, but it is a system created without finalitées politiques. It has been "intended" as politically open.

If we refer back to the sources of European integration, we will find that, regardless of the integration ideology, the elementary activity was connected to a value fundamental for this process, that is the maintenance of peace in Europe. It is in reference to this value that political aims were created, which is clearly emphasised by J. Habermas:

"...it is clear that while the original political aims of European integration have lost much of their relevance, they have since been replaced by an even more ambitious political agenda. The first generation of dedicated Euro-federalist set the process in train after World War II with two immediate purposes in mind: to put an end to the bloody history of warfare between European nations, and to contain the potentially threatening power of a recovering post-fascist Germany" (HABERMAS 2001, 6).

An equally good illustration of the problem is the opinion of the Bundesrat, which states that:

6 The historical reasons for the changeable approach to the state and for the realisation of its value are very complex. In the contemporary European state, this issue is connected to the idea of the state's national character. J. H. H. Weiler emphasises the following aspects of the problem, "I would argue that in the modern notion of the European organic-national nation-state, the state is to be seen principally as an instrument, the organisational framework within the nation is to realise its potentialities. It is within the statal framework that governance, with its most important functions of securing welfare and security, is situated. The well-being and integrity of the state must thus be secured so that these functions may be attained. This is not a meagre value in itself. But to the extent that the state may claim, say, a loyalty which is more than pragmatic, it is because it is at the service of the nation with its values of belongingness and originality." J. H. H. Weiler, European Models: Polity, People and System [in:] P. Craig and C. Harlow (ed.) Lawmaking in the European Union, Kluwer Law International, London 1998, p. 26.

7 The Constitution of the Republic of Poland of 2nd April 1997 as published in Journal of Laws No. 78, item 483, [in:] Polish Constitutional Law. The Constitution and Selected Statutory Materials, Bureau of Research Chancellery of the Sejm, Warsaw 2000. 
"The European Union developed as a project for peace after the Second World War. It is based on shared values. The European Communities' unique political system must adapt to shifting social and political realities if it is to survive."

We must bear in mind, however, that realizing a political goal based on this fundamental value was not equivalent to shaping a political system in the early stages of integration.

The process of European integration, which has lasted for over 50 years, was based on law, strong European legal tradition and legal culture. In my opinion, there are not enough reasons to connect the process with the fulfillment of integrative ideas, which include or represent a specific political model of a community. For the first time in the history of Europe, a system is in the process of creation irrespective of a particular political model. The basis of the system is the law. The acceptation of the law as the basis of the Community was easier since in European culture, especially since the rise of a modern democratic state, yet with clear relation to a much further tradition, e.g. from the ancient Rome, the law and its role in the creation of a social order, as well as the idea of respect of the law, has played a considerable role. Since the very beginning, European system has been more legal than political one, so I prefer the term "Community of Law".9

The formulation of the thesis, that the Community has been based on the law as its foundation, as well as that this basis constituted an original and unique solution in comparison to the previously known forms of social organisation, provokes a question whether the establishment of the Community was an undertaking limited to the economic sphere, or it was expected from the very start to expand its scope of interest from purely economic to a political one.

${ }^{8}$ Decision of the Bundesrat. Bundesrat Resolution on division of competencies in the context of discussions on the future of the European Union. Bundesrat. Drucksache 1081/01 (Beschluss) 20.12.01.

9 I present this problem in my book T. Biernat, Wspólnota prawa. O osobliwościach systemu europejskiego (Community of Law. On Particularities of the European System), Wydawnictwo Adam Marszałek, Torun 2002. The term "Community of law" is often used as 'a polity under the Rule of law. "The EU's ability to establish itself as a "Community of law," i.e. as polity under the Rule of law, has been critically important for propping up its fledging legitimacy." V. Röben, Constitutionalism of Inverse Hierarchy: the Case of the European Union, "Jean Monnet Working Paper", 8, 2003. I use the term "Community of Law" in the broad sense, as a base of the polity. 


\section{THE DEVELOPMENT OF THE EUROPEAN SYSTEM}

The development of the European system, which has grown in such areas as efficient, free market economy, minimum of social security, as well as internal and external safety, economic and monetary union, was like the beginnings of the European integration based on the law. This has led to the emergence of the European Union.

Changes in the European system, particularly its development and widening the field of the decisions, which were taken, have resulted in a visible movement in the direction of a political system from economic community to political community. It is worth emphasising that these changes were forced rather than planned and implemented according to the assumed plan. The process of enlarging the domain of community's authorities has been manifested in the regulations included in the treaties and has caused, or more strictly speaking, has made possible the discussion on the future and the European Union's Constitution. The events that were of crucial effect were the political changes in the 80s and 90s. It was the time when two problems, which have been the subject of a heated scientific discussion, arose, that is "lack of a constitution" and a "deficit of democracy".

The question whether the European Union has a constitution or not is very complex. First of all, it is a political problem. Jean-Claude Piris, the Legal Adviser of the Council of the European Union, and the Legal Adviser of the intergovernmental conferences, who negotiated and adopted the Treaty of Maastricht and the Treaty of Amsterdam, observes that:

“(...) the debate about a 'Constitution for Europe' is mainly a political one. To be or not to be in favour of such a Constitution often means to be or not to be in favour of the establishment of a Federal or a Confederal European State. This political debate is legitimate. Lawyers, however, should try to frame their reflections, as much as they can, on a more legal and institutional basis" (PIRIS 2000).

Differences between opinions represented by various scholars are significant. It is stressed, on the one hand, that the Communities already have a Constitution. On the other hand, the lack of the proper European constitution is sometimes said to be an essential part of the legitimacy deficit of the Union. ${ }^{10}$

10 A. J. Menéndez, presents the following opinion: "European Union already has a material constitution, both in a structural and a substantial sense, but it cannot be said to have a formal constitution or a democratic constitution." A.J. Menéndez, Three Conceptions of the European Constitution, (available at http://www.sv.uio.no/arena/presentation/Menendez.htm) p. 14. 
Another significant element is the phenomenon manifested in a deficit of the EU citizens' participation in its political sphere of life. /Opportunity structures of political participation/. It is an essential characteristic feature of the system and such a feature, which also determines the field of a visibly directed discussion concerning the future of the European Union and the mode of constitutional regulations.

Its participants express the standpoint that a special attention should be paid to the deliberative democratic conception of constitution, e.g. normative conception of the European constitution. The deliberative democratic conception is the most adequate theory in order to reconstruct most of the constitutional traditions of the member states of the EU and the Union itself. What is more, the fact, which is emphasized and taken advantage of, is that deliberative-democratic conception on the constitution defines as constitutional such norms that have met the highest standards of democratic legitimacy. Thus, the democratic principle is clearly associated with the idea of the formation of a common political will in a way, which is respectful for the autonomy of all citizens. ${ }^{11}$

\section{NEW STAGE OF INTEGRATION - ON THE WAY TO THE EUROPEAN CONSTITUTION}

When we pay attention to the development of modern polity, including the European Union, which differs from the state and international organizations, ${ }^{12}$ we can find new bonds in relations between a political system and a constitution. These relations point at the necessity to reach an 'adequate' conception of a constitution. Among numerous suggestions, the one which deserves our attention is to differentiate three conceptions of a constitution, namely formal, material and normative one.

These suggestions are as follows:

"The formal constitution can be defined as a set of legal norms contained in a document (or compilation of documents) that is referred to as the constitution in social practice" (Menéndez, p. 4).

11 Ibidem, p. 10.

12 "While it is easy to give a negative definition of the European Union - it is not a state, not even a federal state, it is not a traditional alliance of states, it is not a confederacy - it is impossible, at least up until now, to define it positively". N. MacCormic, Liberalism, Nationalism and the Post-sovereign State, [in:] R. Bellamy and D. Castiglione, (eds.), Constitutionalism in Transformation: European and Theoretical Perspectives, Blackwell Publishers, Oxford 1996, p. 137. 
The idea of a formal constitution is intrinsically modern. Modernity came hand in hand with the identification of law with written law. The second type is "the material conception of the constitution".

"The material constitution can be defined as the norms of social interaction that are regarded as basic norms according to social practice. Legal scholars tend to refer to the material constitution in a more narrow sense, namely as the norms that can be considered as the basic norms of the legal order of a given community according to the social practice of the legal actors of the said community" (Menéndez, p. 5).

The third type is "the normative conception of the constitution".

"The normative constitution is composed of those norms that present certain properties which are normatively relevant"(...) "The concrete 'ideal' standards to be considered vary with different normative conceptions of the Constitution. There could be as many normative conceptions of the constitution as there are normative theories, that is, theories about what is right" (Menéndez, p. 8-9) ${ }^{13}$.

The differentiation, which has been introduced, seems to be justified from an analytical point of view, what should be emphasized, however, are the existing relations and the interdependency of particular types. In practice none of them exists in pure form, however, the value of such differentiation lies in the possibility of choosing a more adequate type regarding to the problem of constitutionalization of the European system and the process of legitimization. From the point of view of the European system's character 'the material conception of constitution' seems to be more adequate.

The circumstances, which have a decisive significance in this case, are the same ones, which decided about the shape and the development of the European system, namely law and legal culture expressing fundamental values.

An analysis of the binding treaty law and the European Constitution, which has not been passed, carried out on this account points out that they are both determined in a similar way.

Looking at the problem from an axiological perspective, it is possible to trace constitutional elements of the system in the fact that the European Treaty law includes values shared by the Member States, which are common for the democratic constitutional order.

13 The basic insight underlying the normative conception of the Constitution can be derived from Article 16 of the Declaration of the Rights of Man and of the Citizen of 1789. According to the said article, what is the constitution is not something to be determined by mere reference to social practice. 'Ideal' standards (in the sense of counterfactual) play a major role. 
The objectives, stated in Article 2 of the Treaty of the European Union, are the following: promotion of economic and social progress which is balanced and sustainable, assertion of one's own identity on the international scene, strengthening of the protection of the rights and interests of Member State citizens, maintenance and development of the Union's freedom, security and justice as well as, what seems the most significant, the objective to "maintain in full the 'acquis communautaire' and build on it with a view to considering to what extent the policies and forms of cooperation introduced by this Treaty may need to be revised with the aim of ensuring the effectiveness of the mechanisms and the institutions of the Community." Taking into consideration Article 1 Section 1 of the Treaty, which states that:

"This Treaty marks a new stage in the process of creating an ever closer union among the peoples of Europe, in which decisions are taken as openly as possible and as closely as possible to the citizen." ${ }^{14}$

It should be assumed that the achievement of these objectives forms the first priority of this political undertaking.

The political aspect and the "constitutional" character of a certain part of the Treaty law decisions also results from Article 6 of the TEU, in which the axiological foundations of the European treaty law have been stated. Among others, the Article 6 declares that:

"The Union is founded on the principles of liberty, democracy, respect for human rights and fundamental freedoms, and the rule of law, principles which are common to the Member States."

Pointing to the basic values of the Treaty law norms as the ones that constitute the European Union does not, however, mean that the system has its own constitution. The analogy with constitutional norms, does not end at the level of the system's institutions (system governed norms), whereas the constitution undisputedly performs additional functions. This basic problem can be characterised in the following way:

"Each idea of law must assume a particular position as to how to resolve the conflict between the rights of an individual and common good. Each legal order is based on a particular sort of political philosophy, from which we draw directions concerning our conduct in case of a conflict between the rights of the individual and common good." 15

${ }^{14}$ Quoted according to: Consolidated version of the Treaty on European Union and of the Treaty establishing the European Community (consolidated text) "Official Journal" C 321E of 29 December 2006.

${ }^{15}$ L. Morawski, Prawa jednostki a dobro wspólne. Liberalizm versus komunitaryzm. (Rights of the Individual and Common Good. Liberalism versus Communitarism), "Państwo i Prawo" (“The State and Law") 11(633), 1998, p. 26. 
This problem is also stressed by Volken Röben:

"Every polity is based on a conception of the relations between public power, society and an individual. In the humanistic view of an individual, inherent human rights are universal, their source cannot be found in a state or an international act. Yet a constitution allows for a secondary formulation of human rights as rational self-limitation of power, thus legitimizing the public authority by limiting its reach."16

It is true that the TEU confirms in the Preamble the attachment to and respect for human rights and the attachment to fundamental social rights. Particularly, Article 6 Section 2 of the TEU states that :

"The Union shall respect fundamental rights, as guaranteed by the European Convention for the Protection of Human Rights and Fundamental Freedoms signed in Rome on 4 November 1950 and as they result from the constitutional traditions common to the Member States, as general principles of Community law."

However, constitutionalisation in this respect is evident and it is well manifested in Part II of the Treaty establishing a Constitution for Europe ${ }^{17}$. The Charter of fundamental rights, solemnly proclaimed by the Parliament, the Council and the Commission on 8 December 2000, was not part of the Union's Treaties and had no binding legal force. At present, the Charter is incorporated into the European Constitution as Part II "The Charter of Fundamental Rights of the Union." According to the Preamble:

"This Charter reaffirms, with due regard for the powers and tasks of the Union and for the principle of subsidiarity, the rights as they result, in particular, from the constitutional traditions and international obligations common to the Member States, the European Convention for the Protection of Human Rights and Fundamental Freedoms, the Social Charter adopted by the Union and by the Council of Europe and the case law of the Court of Justice of the European Union and of the European

16 V. Röben, op. cit.

17 In this essay I use the notion 'European Constitution' as an equivalent for the Treaty establishing a Constitution for Europe, "Official Journal of the European Union”, C 310 Volume 47, 16 December 2004. The use of such an equivalent term is not only a mere simplification. In this way I emphasise "a constitutional character of this legal act". I fully agree with Rainer Arnold's standpoint on this issue expressed in a monograph: R. Arnold, The Different Levels of Constitutional Law in Europe and Their Interdependence, [in:] Challenges of MultiLevel Constitutionalism, (ed.) J. Nergelius, P. Policastro, K. Urata, Polpress Publisher, Kraków 2004, pp. 105-106. The final version of this essay has been prepared before approving the Treaty of Lisbon amending the Treaty on European Union and the Treaty establishing the European Community, signed at Lisbon, 13 December 2007. "Official Journal" C 306 of 17 December 2007. 
Court of Human Rights. In this context the Charter will be interpreted by the courts of the Union and Member States with due regard to the explanations prepared at the instigation of the Praesidium of the Convention which drafted the Charter and updated under the responsibility of the Praesidium of the European Convention."18

The content of the Charter is broader than that mentioned in Article 6 of the TEU and in the European Convention for the Protection of Human Rights and Fundamental Freedoms, signed in Rome on 4 November 1950. The areas such as the right to proper administration, personal data protections, bioethics and others have been included in the Union Charter. But the constitutional solution is, first of all, the legally confirmed coherence of the human rights protection system. It is stressed in Article II-52 section 4 of the Treaty establishing a Constitution for Europe state that:

"Insofar as the Charter recognises fundamental rights as they result from the constitutional traditions common to the Member States, those rights shall be interpreted in harmony with those traditions."

\section{A FALSE DILEMMA}

Discussion on the future of the European Union, the European Constitution, the extent and direction of European integration has been improperly directed. Instead of emphasising such elements and solutions which reflect common European traditions and which are deeply grounded in legal culture, or even in constitutional culture, opposing aspects are being stressed otherwise. It is true that even they have their justification in tradition and legal culture but in such a dimension, which refers to values not shared commonly. Instead of solidarity there is particularity of interests, instead of cooperation there is an egoistically perceived privileged position and advantage.

Such a way of directing the discussions has determined the process of making particular attitudes common, both in the circle of politicians and in the European society. These attitudes have caused a failure of the efficiency and legitimacy of the European Constitution. To simplify, it consisted in formulating alternative visions: either a constitution and then we deal with certain threat like the European federal state and the loss of sovereignty of the member states or rejecting the constitution irrespective of its content.

The notion that the material constitution is relevant in the European system has its confirmation in the constitution making process. The process of forming the

${ }^{18}$ Charter of Fundamental Rights of the European Union, "Official Journal" C 303 of 14 December 2007. 
European constitution was an act of adjusting fundamental legislative solutions to an already existing system; it was neither an act of creation, nor it introduced changes as deep and significant as to be called an act of transformation. In a case like this, a constitutional act has more of a stabilizing or modifying than revolutionary function..$^{19}$ Stressing this feature, I am emphasizing a particular dependence of the constitutional process on facts and on the existing reality, rather than on ideological or doctrinal choices. As a consequence, the particular features of the current Communities and the existing legal solutions delimit the boundaries of the European system's changes. These features and solutions restrict provisions concerning the constitution, and, in doing so, they exert a predominant influence upon their content. Such dependence marks that the creation of the European constitution was rooted in the type of system which limits the European Constitution..$^{20}$ From that reason the thesis that legitimacy 'anchored' in a deep structure of the system can play a significant role in renewing the processes of legitimising new norms or institutions, has a particular meaning in relation to the European Union. These legitimated elements of the system are a fundamental source of legitimacy of the European constitution. ${ }^{21}$

I do not carry out a detailed analysis of the content of the Treaty establishing a Constitution for Europe from the point of view of the changes implemented to the European Union's legal order, but the above mentioned opinion about a stabilizing and modifying function has been manifested in the legal solutions included in the document submitted to the member states for ratification.

It should be noted that a number of solutions, if not perfect but positively modifying the current state by its clarification, have appeared in this document. The

19 See V. Röben's opinion: “The Nice Declaration, the Laeken Mandate, and the Draft Constitutional treaty as it has emerged from the deliberations of the Convention are best read as aiming at reformation, not at revolution, of this model of constitutionalism." V. Röben, op. cit.

${ }^{20}$ More on this issue see; Tadeusz Biernat, The Origins and the Limits of the European Constitution, "Archiwum Iuridicum Cracoviense", Vol. XXXV-XXXVI, 2002-2003.

${ }^{21}$ It is the reason why the problem of legitimizing a constitution cannot come down to the way it is created. Neither convening the Convention nor its composition or course of activities was of importance in this context. Similarly, we cannot attach too much importance to the charges that the creation of the constitution did not meet democratic standards in the period of discussing the content of created law. It is primarily the question of paradigms of constitutionality. See P. Policastro, On the Reconstruction of the Legal Strength of the Constitution in a World in Transition. Multi-Level Constitutionalism Towards Multi-Level Democracy, [in:] Challenges of Multi-Level Constitutionalism, (ed.) J. Nergelius, P. Policastro, K. Urata, Polpress Publisher, Kraków 2004. pp. 59-60. 
examples of such solutions are, first of all, clarification and classification of the Union's powers, simplification of the Union's legal instruments.

I refer to what took place in May 2005 as a legitimizing paradox. On the one hand, we deal with an accepted system, developing naturally, in which a successful economic integration, turned systematically into more extensive unification that concerns political aspects of the social order, has become a self-constituting process. On the other hand, the attempt to order a legal basis of the existing system without implementing revolutionary changes is blocked in French referendum.

An explanation of this paradox is possible in many ways and discussing even the most crucial ones would require a separate monograph. Starting with such explanations that 'the No vote also had more to do with emotion than reason', and finishing with an opinion expressed by a constitutional expert that 'this No was about everything' ${ }^{22}$. If we look at this problem from the perspective of "the conditions of legitimization", one reason seems to be of utmost importance. This reason is a failure to perceive changes in the constitutional process of a new generation. The Laeken Declaration was, beside the Declaration on the Future of Europe annexed to the Final Act of the Nice Intergovernmental Conference, a corner stone of the constitution making process. Justification of the assumed activities has been given the label: 'Europe at the crossroads'. The steps, which were taken, meant a proper choice of direction. The fact that the assumed goal has not been reached does not result merely from the strategies taken up by the politicians of the member states. Some disorientation has arrived in the way of the latter, partly as a result of the above mentioned misunderstandings.

The events that have taken place after May 2005, particularly in the context of further enlargement of the European Union of two new member states, namely Bulgaria and Romania, confirm the above mentioned theses. On the one hand, there arises the need to introduce adequate legal changes on the level of the European system's organization and, on the other hand, implementation of these changes faces obstacles which are difficult to overcome. Even in the situation when the "constitutional approach", arousing irrational fears, was abandoned and replaced by proven means of preparing the EU Reform Treaty. The Treaty signed by the Heads of State or Government of the 27 Member States in Lisbon on 13 December 2007 which provide the EU with modern institution and optimized working methods is a final act of a very difficult compromise. It is far from being perfect because at the present level of "integrity consciousness" and agreed decisions concerning the choice of future community it is hardly possible, however, it is indispensable. In spite of the latter,

${ }^{22}$ Dilemma for Chirac as voters say No to everything, "Financial Times", Europe, Tuesday, 31.05.2005 
what can be well visible is the aforementioned paradoxical situation. Similarly to the Constitutional Treaty, we face political impasse created by Ireland's rejection. Unfortunately, Poland has become a part of this paradox on account of the decisions taken by the President of Poland, who actively participated in the most crucial moment, that is the final stage of the negotiations of the Treaty, accepted its solutions and currently he refuses signing the EU Reform Treaty.

The discussion about a constitution in the material meaning, legitimization of the assumed solutions ${ }^{23}$ and its popularity in the European community can contribute to find a proper way. The European legal culture can be the most important factor in it. However, it depends on the degree to which the aura and the basis of over-national, intercultural recognition of the function of legal culture can be created.

${ }^{23}$ This problem has been pointed at from the very beginning in the documents of the Convention: "The first and most important condition is the legitimisation of the consensus that would need to be embodied in such a constitution regarding the form of the 'European Union' as a political entity or polity." Convention Bulletin Edition 09 - 13.06.02. Constitutional - convention.net 